\title{
Destination Management: The Influence of Local Food
}

Research Article

Samantha Morris, Tomás Dwyer* and Julie Mulligan

Institute of Technology Carlow, Ireland

Abstract: This study investigates tourist attitudes to local food on destination choice, travel motivation, satisfaction and perceived object-related and existential authenticity. Additionally, the mediating effects of authenticity on these relationships is also examined. A quantitative survey $(n=368)$ by questionnaire was conducted. Data was analysed using factor analysis and Structural Equation Modelling (SEM) to show that tourist attitudes to local food influence destination choice, satisfaction and perceptions of object-related and existential authenticity. Furthermore, it was found that existential authenticity, rather than object-related authenticity had a greater impact on the relationships between tourist attitudes to local food and destination choice, travel motivation and satisfaction. A clear and influential relationship between tourists' attitudes to local food and travel behaviour was found. Tourists want an existential authentic local food experience where they can be actively involved. Destinations should emphasise unique regional specialities and highlight the experiential value of local food.

Keywords: local food tourism; attitudes; object-related authenticity; existential authenticity

(c) Sciendo

\section{INTRODUCTION}

Food is a critical tourism resource. Furthermore, local food can be an attraction in its own right (Björk and KauppinenRäisänen, 2014; 2017; Henderson, 2009) appealing to those seeking authentic and novel experiences (Okumus et al., 2007; Sims, 2009). Local food has become an important factor in the tourist experience and a key determinant in tourist destination choice (Cohen and Avieli, 2004). Additionally, local food is important for tourist satisfaction (Cetin and Bilgihan, 2016). This study investigates the influence of tourist attitudes to local food on destination choice, travel motivation, satisfaction and authenticity.

It is acknowledged that for some tourists local food and food experiences are not an essential part of their holiday (López-Guzmán and Sánchez-Canizares, 2012; Björk and Kauppinen-Räisänen, 2014). However, local food may attract those tourists who are committed to food and explicitly search for extraordinary local food experiences (Cohen and Avieli, 2004; Kivela and Crotts, 2009; McKercher et al., 2008; Mitchell and Hall, 2003; Smith and Costello, 2009).

Despite a growing interest in food tourism (Ellis et al., 2018; Björk and Kauppinen-Räisänen, 2017, 2016; Chandralal and Valenzuela, 2013; Robinson and Getz, 2016) few studies have examined whether tourists' attitudes to local food can influence their travel behaviour (Chen and Huang, 2019; Sims, 2009). Particularly, the interrelationships between tourist attitudes towards local food, destination choice, motivation and satisfaction remain relatively unexplored (Williamson and Hassanli, 2020; Henderson, 2009; Sims, 2009).

Authenticity is a vital component of the visitor experience. It can act as an underlying driver in tourist destination choice (Richards, 2012), travel motivation (Mak et al., 2017) and satisfaction (Cetin and Bilgihan, 2016). Local food embodies authenticity (Jang et al., 2011; Ram et al., 2016), therefore, it can be argued that tourists who search 
for local food are also on a quest to find authenticity (Sims, 2009). In food tourism, authenticity has been studied from two perspectives; object-related and existential. Object-related authenticity refers to whether something can be conveyed and interpreted as authentic or not (Wang, 1999, cited in Sims, 2009). It is based on the genuineness of objects and is verified by an expert. While existential authenticity is where the tourist forms an understanding of authenticity based on their beliefs, expectations or previous experiences (Sims, 2009). Studies support the idea that tourists perceive local food as authentic products symbolising the culture and heritage of a place (Sims, 2009). However, the link between attitudes to local food and authenticity is relatively unexplored. Furthermore, Robinson and Clifford (2012), suggest that the mediating role of authenticity in food consumption experiences warrants further attention.

Taking these points into consideration, there are a number of research gaps relating to attitudes, local food travel behaviour and authenticity. Therefore, to address these identified gaps, the objective of this paper is twofold. Firstly, to investigate the influence of tourist attitudes to local food on destination choice, travel motivation, satisfaction and perceived authenticity. Secondly, to examine the effect of object-related and existential authenticity on these relationships.

The remainder of the paper is organised as follows. In the next section, a review of the literature pertaining to tourist attitudes to local food and destination choice, travel motivation, satisfaction and authenticity are presented. Several hypotheses are proffered, and a conceptual framework presented. Subsequently, the methodology is outlined including information about the scale development, data collection, sample and data analysis and SEM development. Consequently, the results of the hypotheses are outlined followed by a discussion of the results. The paper concludes with an overview of the contribution of this study to the research field and the limitations of the study.

\section{LITERATURE REVIEW AND HYPOTHESES DEVELOPMENT}

\section{Local food and destination choice}

Consumers are increasingly interested in local food (Williamson and Hassanli, 2020; Ellis et al., 2018; Hjalager and Richards, 2002). Research shows that for some tourists, food represents a 'pull' factor and a reason to choose a specific destination (Su et al., 2018). Tourists may be drawn to a region to sample a Michelin starred restaurant, such as Noma in Denmark. Additionally, tourists may be attracted to a destination based on regional specialities, for example, tapas in Seville or pintxos in San Sebastian. In contrast, foods such as paella in Valencia or pizza in Naples may be perceived as an essential part of the holiday experience but may not entice tourists to choose a certain destination (Bjork and Kauppinen-Räisänen, 2016). In a similar manner, tourists who have a casual interest in food may value local food at a destination as a traditional and authentic part of the culture and heritage (Hjalager, 2003; Sims, 2009). However, few studies have investigated the influence of attitudes to local food as an antecedent in destination choice. Consequently, the following hypothesis is presented:

\section{H1: Tourist attitudes to local food positively influence destination choice.}

\section{Tourist attitudes to local food and motivation to travel}

'Push factors' are features that influence an individual to travel (Dann, 1977). Several studies have established that local food can be a 'push' factor which can motivate individuals to travel for a number of reasons. Firstly, the sensory experience of local food can be a primary motivation for travelling (Su et al., 2018; Boniface, 2003; Kim \& Eves, 2012). Secondly, local food can represent an interpersonal motivator as meals taken on a holiday have a social function enabling the building of new social relations and the strengthening of social bonds (Crompton, 1979; Fields, 2002). Thirdly, local food provides a cultural experience, providing an individual with the opportunity to learn about different countries and traditions (Kim and Eves, 2012) and a chance to engage in authentic experiences. Fourthly, local food can appeal to those looking for an exciting and different experience (Kim and Eves, 2012), to escape a daily routine. Finally, tourism and gastronomy are often regarded as hedonic products (Kivela and Crotts, 2006), for which fun, pleasure, or enjoyment is a primary benefit. Hence, the 'pleasure' factor can be an inherent motivating factor in food tourism. 
Additionally, on examining the various definitions for food tourism it was found that the majority consider food as a primary motivating factor to travel (Boniface, 2003; Crompton, 1979; Dann, 1981; Hall and Sharples, 2003). For example, Smith and Costello (2009, p. 49) define food as being a 'principal resource', which encourages 'individuals to travel and visit a destination specifically for the unique food products. Similarly, Su (2013, p. 574) claim that tourists can be 'partly or largely' motivated by the food experience. From this perspective, food can also be positioned as an important secondary motivation. As such, Su (2013) contends that food represents one motivating factor to travel, but it is not necessarily the primary reason. If local food can act as a 'pull factor' enticing tourists, then it could be argued that interest in local food could be an antecedent, thus influencing travel motivation. Accordingly, the following hypothesis was formed:

\section{H2: Tourist attitudes to local food positively influence motivation to travel.}

\section{Tourist attitudes towards local food and holiday satisfaction}

Satisfaction is considered the outcome of a subjective evaluation of whether something meets or exceeds the needs of the individual (Oliver, 1980). It is argued that local food and local food experiences are an important source of enjoyment during a holiday (Kivela and Crotts, 2006), having a positive effect on overall holiday satisfaction (Sánchez-Cañizares and López-Guzmán, 2012; Henderson, 2009). However, tourist satisfaction is a multifaceted concept and influenced by various attributes including; perceived value, the destination environment and the tourist themselves (Andersson and Mossberg, 2017; Mak et al., 2012; Kauppinen-Räisänen et al. 2013). In addition, local food experiences can also determine tourist satisfaction (Björk \& Kauppinen-Räisänen, 2014). Furthermore, local food experiences can add to the holistic or overall holiday experience (Bjork and Kauppinen-Räisänen, 2017).

Prior research has also demonstrated that customer satisfaction significantly influences future behavioural intentions (Oliver and Burke, 1999) such as revisit intention and positive word-of-mouth. Therefore, positive local food experiences may influence revisit intention and may encourage positive word of mouth (Björk \& KauppinenRäisänen, 2016; Sánchez-Cañizares and López-Guzmán, 2012). On the other hand, negative experiences with local food may cause the opposite behaviour.

Moreover, studies suggest that attitudes towards local food can be predictors and determinants of customers' satisfaction (Bell and Marshall, 2003; Cohen and Avieli, 2004; Kim et al., 2010; Björk and Kauppinen-Räisänen, 2017). Consequently, it is hypothesised that:

\section{H3: Tourist attitudes to local food positively influence holiday satisfaction.}

\section{Tourist attitudes towards local food and perceptions of authenticity}

A wide range of attempts have been made to define the concept of authenticity. As a result, 'there are at least as many definitions of authenticity as there are those who write about it' (Taylor, 2001, p. 8). However common themes emerge with words such as original, real, genuine, true and honest often used (Özdemir and Seyitoğlu, 2017). Authenticity is recognised as an important aspect of the food tourism experience (Ellis et al., 2018) with local food recognised as part of the culture, heritage and traditions of a place (Sims, 2009).

In food tourism, authenticity has been studied from two perspectives; object-related and existential. Objectrelated authenticity refers to whether something can be conveyed and interpreted as authentic or not (Wang, 1999, cited in Sims, 2009). It is based on the genuineness of objects and is verified by an expert. While existential authenticity is where the tourist forms an understanding of authenticity based on their beliefs, expectations or previous experiences (Sims, 2009). It is argued that object-related and existential based authenticity can significantly influence tourist attitudes and the intention to purchase local food (Sidali and Hemmerling, 2014). Therefore, it can be argued that a high level of perceived authenticity is likely to lead to a more positive attitude and a higher level of purchase intention among tourists. Accordingly, the following hypothesis is proposed:

H4: Tourist attitudes to local food positively influence the perception of (a) object-related (b) existential authenticity.

\section{The influence of authenticity on travel behaviour}

Research suggests that the quest for authenticity can act as an underlying driver in tourist destination choice (Beer, 2008; Richards, 2012), travel motivation (Mak et al., 2017; McKercher et al., 2008) and satisfaction (Cetin and 
Bilgihan, 2015). Furthermore, tourists' increasing demand for local food can be linked to the search for authenticity (Sims, 2009). Yet there is a lack of research seeking to understand the effects of authenticity on the relationships between tourist attitudes to local food and destination choice, motivation to travel and satisfaction. This research will, therefore, seek to understand if authenticity has an influence on these relationships. As authenticity is measured from two perspectives, object-related and existential, the following hypotheses are proposed:

H5.1: Object-related authenticity mediates the relationship between tourist attitudes to local food and (a) destination choice, (b) motivation to travel and (c) satisfaction.

H5.2: Existential authenticity mediates the relationship between (a) destination choice, (b) motivation to travel and (c) satisfaction.

A summary of the themes in the literature presented leading to the development of the hypotheses is presented in Table 1.

Table 1: Literature themes as they relate to hypothesis development

\begin{tabular}{|c|c|c|}
\hline Theme & Motivation & Hypothesis \\
\hline Local food and destination choice & Pull & H1: Tourist attitudes to local food positively influence destination choice \\
\hline \multirow{2}{*}{$\begin{array}{l}\text { Tourist attitudes to local food and motivation } \\
\text { to travel }\end{array}$} & Push & \multirow{2}{*}{ H2: Tourist attitudes to local food positively influence motivation to travel } \\
\hline & Pull & \\
\hline $\begin{array}{c}\text { Tourist attitudes towards local food and holiday } \\
\text { satisfaction }\end{array}$ & Pull & H3: Tourist attitudes to local food positively influence holiday satisfaction \\
\hline $\begin{array}{l}\text { Tourist attitudes towards local food and } \\
\text { perceptions of authenticity }\end{array}$ & Pull & $\begin{array}{l}\text { H4: Tourist attitudes to local food positively influence the perception of (a) } \\
\text { object-related (b) existential authenticity. }\end{array}$ \\
\hline \multirow{2}{*}{$\begin{array}{c}\text { The influence of authenticity on travel } \\
\text { behaviour }\end{array}$} & \multirow{2}{*}{ Push } & $\begin{array}{l}\text { H5.1: Object-related authenticity mediates the relationship between tourist } \\
\text { attitudes to local food and (a) destination choice, (b) motivation to travel and } \\
\text { (c) satisfaction. }\end{array}$ \\
\hline & & $\begin{array}{l}\text { H5.2: Existential authenticity mediates the relationship between (a) destination } \\
\text { choice, (b) motivation to travel and (c) satisfaction. }\end{array}$ \\
\hline
\end{tabular}

\section{FRAMEWORK DEVELOPMENT}

The Hypotheses formed the basis of the conceptual framework as presented in Figure 1. The previous discussion infers that tourist attitudes to local food are a determinan of destination choice, travel motivation and satisfaction. The framework proposes that object-related and existential authenticity have a direct effect on each of these relationships. The framework hypotheses to be tested are outlined below.

Direct effects hypotheses:

H1: Tourist attitudes to local food positively influence destination choice.

$\mathrm{H} 2$ : Tourist attitudes to local food positively influence motivation to travel.

H3: Tourist attitudes to local food positively influence holiday satisfaction.

H4: Tourist attitudes to local food positively influences authenticity.

Mediated effects hypotheses:

H5.1: Object-related authenticity mediates the relationship between tourist attitudes to local food and (a) destination choice, (b) motivation to travel and (c) satisfaction.

H5.2: Existential authenticity mediates the relationship between tourist attitudes to local food and (a) destination choice, (b) motivation to travel and (c) satisfaction. 


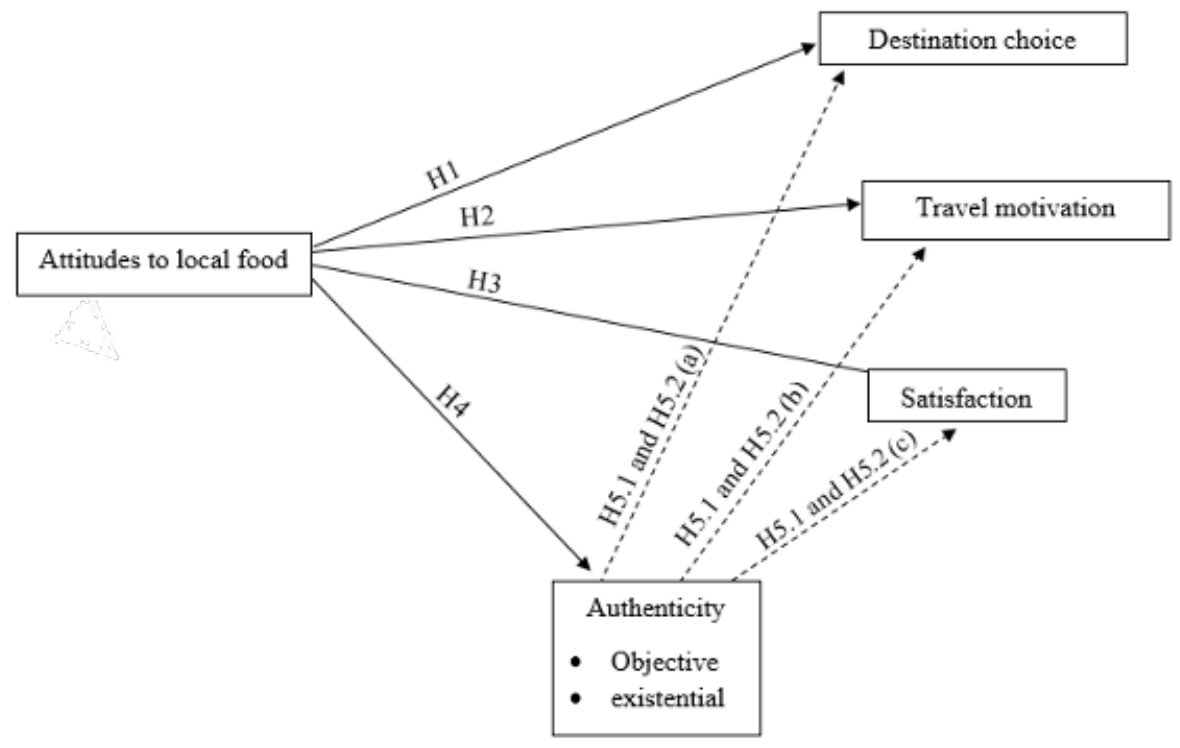

Figure 1: Conceptual Framework: attitudes to local food and travel behaviour mediated by authenticity

\section{METHODOLOGY}

A quantitative approach was applied in this research using a questionnaire distributed by means of both online and face-to-face data collection. The population of interest was identified as food tourists, defined as those 'who plan their trips partially or totally in order to taste the cuisine of the place or to carry out activities related to gastronomy' (United Nations World Tourism Organisation (UNTWO), 2012, p. 7).

Scales were developed to measure each construct through an examination of the literature pertaining to food tourism and local food and the adaptation of tested constructs. Six scales were developed including; attitude to local food (Attitudes_LF), destination choice (Mot_Des), motivation to travel (Mot_Travel), satisfaction (Satisfaction), object-related authenticity (Obj_A) and existential authenticity (Exa_A). The questionnaire using a five-point Likert scale ( $1=$ strongly disagree, $5=$ strongly agree) was designed to capture data for each construct of the research framework. The questionnaire was pilot tested at a food festival in County Wexford in the Republic of Ireland on the 13th July 2018 among fourteen respondents. Respondents were encouraged to comment on any aspect of the questionnaire.

Following the pilot test, some questions were rephrased to clarify meaning.

\section{Sample and data collection}

This research concerns food tourists, and as such certain criteria needed to be met by each respondent to be eligible for inclusion in the study. Therefore, a non-probability sampling strategy was employed. This led the researcher to adopt a purposive criterion sampling technique (Patton, 2001). Consequently, the following inclusion criteria were used to identify eligible respondents:

1. All respondents must have had an interest in food and food experiences

2. All respondents must have experience of domestic or international holidays

3. All respondents must have been 18 years old and over

By employing these criteria, it ensured that the respondents had an acceptable interest in travel, food and food experiences to answer the questionnaire. Furthermore, a similar sampling strategy was employed in previous food tourism studies (for example, Boesen et al., 2017; Everett, 2012; Mak et al., 2017). 
A sample size $>300$ was required to conduct Structural Equation Model (SEM), (Tabachnick and Fidell, 2013), therefore two methods of data were employed; face-to-face and online. For face-to-face data collection, the researcher approached respondents at two food festivals on the $7^{\text {th }}$ and $8^{\text {th }}$ September 2018 and the $26^{\text {th }}$ and $28^{\text {th }}$ October 2018. These data collection points were deemed suitable by the arguments that people who visit these events can be defined as food tourists, as defined by the UNTWO, and will have varying demographic profiles.

Secondly, the survey was circulated online with potential respondents identified through an online search of food interest groups. Additionally, the email asked the recipient to share the link to the survey with other members of their respective groups. The initial email invite was sent out to 425 recipients on the $12^{\text {th }}$ November 2018 with a follow-up reminder sent on $18^{\text {th }}$ November 2018. The online survey was active for two weeks from the $12^{\text {th }}-26^{\text {th }}$ November 2018. The final response rate was 368 ; face-to-face data collection $n=101$ while online $n=253$.

\section{Data analysis}

The data was analysed using both SPSS and SPSS Amos (version 24) software. To measure the multi-dimensional latent variables in the questionnaire, a Structural Equation Model (SEM) was used in this study.

Data screening procedures were performed to ensure usability, validity and reliability prior to testing the hypotheses as presented in Table 2. As such checks were made for missing data and both multivariate and univariate outliers. Additionally, data was tested to ensure it achieved suitable levels of Skewness and Kurtosis. Finally, data were screened for issues of multicollinearity, homoscedasticity, linearity.

Exploratory factor analysis (EFA) was used to detect discriminant validity issues, whereby the constructs in the framework were refined into a usable set of 'coherent subscales' (Pallant, 2011, p. 179). A successful EFA requires several thresholds to be achieved. Firstly, the appropriateness of the data is assessed using the KMO $(0.914=$ Good $)$. Secondly, Bartlett's Test of Sphericity $($ Sig. $<0.000=$ Good $)$ ensures that the variables included in the analysis sufficiently relate to one another to confirm a meaningful EFA. Next, the pattern matrix produced by the EFA is assessed for convergent validity and discriminant validity. Convergent validity assesses the degree to which variables within a single factor are correlated (Hair et al., 2013). Hair et al. (2013) suggests that with a sample size $>250$ a factor loading of 0.4 is significant. As the sample size in this research was 368 all variables with factor loadings above 0.4 were deemed significant. Discriminant validity assesses the degree to which factors are distinct and uncorrelated. To satisfy discriminant validity correlations between factors should not exceed 0.7 and cross-loadings should differ by $>0.2$. Both convergent and discriminant validity were achieved in the analysis. Subsequently, the reliability of the framework measures was assessed using Cronbach's alpha coefficient, which explored the internal consistency of the scales. All values were more than 0.7 and therefore reliability was assured (Hair et al., 2013).

The next step in scale development was to perform a confirmatory factor analysis (CFA).

The primary function of CFA is to confirm the factor structure of the framework from the EFA, checking if the measurement model has goodness of fit (Gaskin, 2010). Firstly, factor loadings, composite reliability and average variance extracted were used to measure convergence validity (Hair et al., 2013). Each of these tests was conducted using the Stats Tools Package for Microsoft Excel, as developed by Gaskin (2012). The results of the analysis are displayed in Table 2.

Table 2: Confirmatory Factor Analysis (CFA) results of the measurement model

\begin{tabular}{|c|c|c|c|c|c|c|c|c|c|c|}
\hline & CR & AVE & MSV & $\underset{\text { (H) }}{\operatorname{Max}}$ & Exa_A & $\begin{array}{l}\text { Mot_ } \\
\text { Travel }\end{array}$ & $\begin{array}{c}\text { Attitudes_ } \\
\text { LF }\end{array}$ & Satisfaction & Obj_A & $\begin{array}{l}\text { Mot } \\
\text { Des }\end{array}$ \\
\hline Exa_A & 0.668 & 0.502 & 0.494 & 0.672 & 0.709 & & & & & \\
\hline Mot_Travel & 0.906 & 0.707 & 0.638 & 0.908 & 0.615 & 0.841 & & & & \\
\hline Attitudes_LF & 0.833 & 0.602 & 0.304 & 0.887 & 0.528 & 0.402 & 0.776 & & & \\
\hline Satisfaction & 0.876 & 0.640 & 0.319 & 0.894 & 0.565 & 0.502 & 0.538 & 0.800 & & \\
\hline Obj_A & 0.863 & 0.679 & 0.238 & 0.874 & 0.371 & 0.396 & 0.488 & 0.342 & 0.824 & \\
\hline Mot_Des & 0.824 & 0.702 & 0.638 & 0.850 & 0.703 & 0.799 & 0.551 & 0.531 & 0.381 & 0.838 \\
\hline
\end{tabular}


From the results, the measurement model has composite reliability $(\mathrm{CR})$ as evidenced by all values $>0.6$. Furthermore, it has convergent validity as evidenced by the AVE results $>0.5$ which is in line with Barclay et al. (1995) who recommend achieving a score of greater than 0.50. Additionally, the measurement model has discriminant validity as the MSV value is less than the AVE. Moreover, the square root of the AVE, of all factors is greater than any the inter-factor correlations, as shown in bold on the diagonal of the matrix in Table 2. Therefore, all six constructs the framework; 1) attitude to local food, 2) destination choice, 3) motivation to travel, 4) satisfaction 5 ) object-related authenticity 6) existential authenticity, are valid measures of their corresponding concepts based on their reliability, validity and statistical significance.

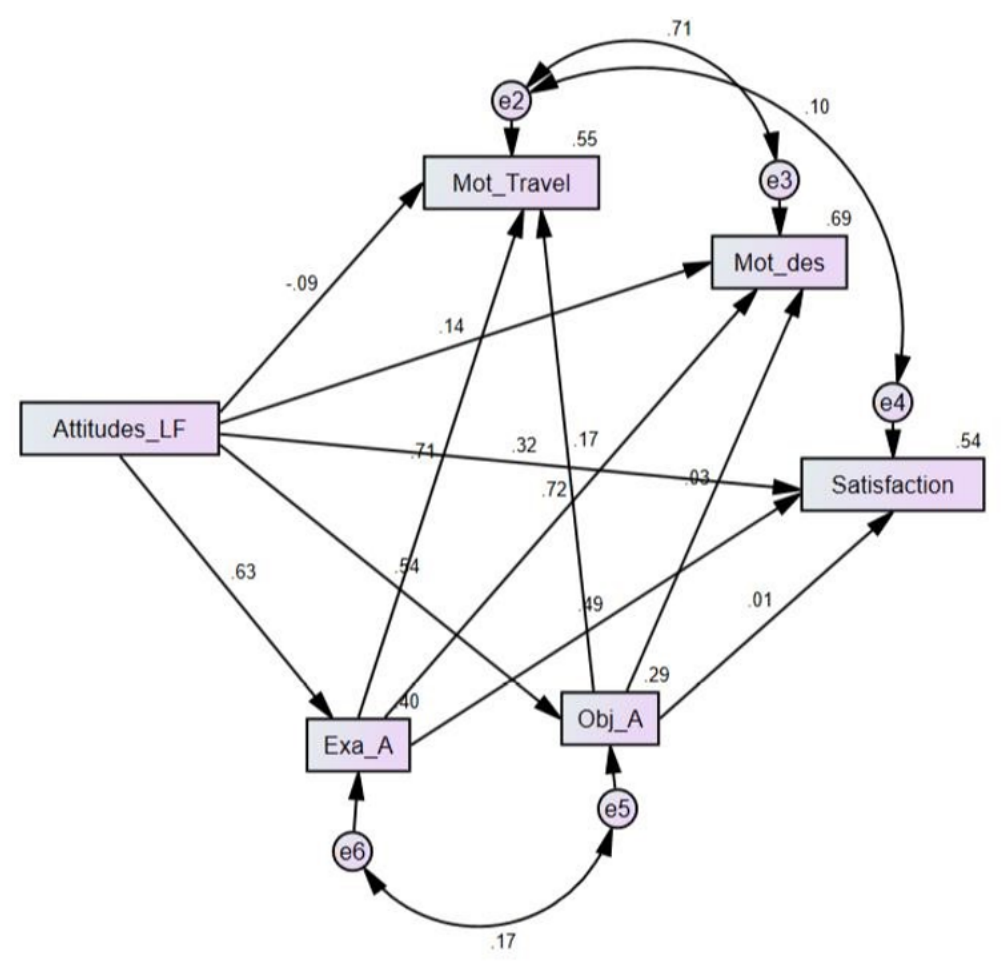

Figure 2: Structural model showing regression weights from the standardised estimates output

The next stage of the analysis involved generating a full structural equation model (SEM) using Maximum Likelihood estimation for the sample, as shown in Figure 2. The model fit indicators were RMSEA $=0.06$ (acceptable), SRMR $=0.003$ (Excellent), CFI = .955 (excellent) and CMIN/DF= 2.324 (excellent). These results support a good model fit (Lowry and Gaskin 2014).

\section{Results of hypotheses}

The results for the framework support the direct effects of $\mathrm{H} 1, \mathrm{H} 3, \mathrm{H} 4$ (a) and $\mathrm{H} 4$ (b). It did not support $\mathrm{H}$ 2, as presented in Table 3. Additionally, the mediated effects of H5.1 (b), H5.2 (a), H5.2 (b) and H5.2 (c) were supported. $\mathrm{H} 5.1$ (a) and H5.1 (b) were rejected, as reported in Table 4. 
Table 3: Results of direct hypothesis

\begin{tabular}{clccc}
\hline Hypothesis & \multicolumn{1}{c}{ Predictor } & Outcome & $\begin{array}{c}\text { Std Beta } \\
(\beta)\end{array}$ & Decision on hypotheses \\
\hline \hline $\mathrm{H} 1$ & Attitude towards local food & Destination choice & $0.136^{\star \star \star}$ & Accept \\
$\mathrm{H} 2$ & Attitude towards local food & Motivation to travel & $-0.89 \#$ & Reject \\
$\mathrm{H} 3$ & Attitude towards local food & Satisfaction & $0.320^{\star \star *}$ & Accept \\
$\mathrm{H} 4(\mathrm{a})$ & Attitude towards local food & Object-related authenticity & $0.542^{\star \star *}$ & Accept \\
$\mathrm{H} 4$ (b) & Attitude towards local food & Existential authenticity & $0.629^{\star * *}$ & Accept \\
\hline
\end{tabular}

Significance of correlations: ${ }^{* * *} p<0.001,{ }^{* \star} p<0.010,{ }^{*} p<0.05, \# p<0.100$.

Table 4: Framework mediators - indirect effects [Bootstrap 2000 samples and 95\%Cl]

\begin{tabular}{|c|c|c|c|c|c|c|c|}
\hline Hypotheses & Direct path & Mediator & Estimate & Lower & Upper & p value & $\begin{array}{l}\text { Decision on } \\
\text { mediation }\end{array}$ \\
\hline H5.1 (a) & $\begin{array}{l}\text { Attitude towards local food } \\
\rightarrow \text { Destination choice }\end{array}$ & $\begin{array}{l}\text { Object-related } \\
\text { authenticity }\end{array}$ & 0.025 & 0.019 & 0.071 & 0.341 & Reject \\
\hline H5.1 (b) & $\begin{array}{l}\text { Attitude towards local food } \\
\rightarrow \text { Motivation to travel }\end{array}$ & $\begin{array}{l}\text { Object-related } \\
\text { authenticity }\end{array}$ & 0.168 & 0.091 & 0.257 & 0.001 & Accept \\
\hline H5.1 (c) & $\begin{array}{l}\text { Attitude towards local food } \\
\quad \rightarrow \text { Satisfaction }\end{array}$ & $\begin{array}{l}\text { Object-related } \\
\text { authenticity }\end{array}$ & 0.004 & 0.039 & 0.052 & 0.833 & Reject \\
\hline H5.2 (a) & $\begin{array}{l}\text { Attitude towards local food } \\
\rightarrow \text { Destination choice }\end{array}$ & $\begin{array}{l}\text { Existential } \\
\text { authenticity }\end{array}$ & 0.618 & 0.547 & 0.697 & 0.001 & Accept \\
\hline H5.2 (b) & $\begin{array}{l}\text { Attitude towards local food } \\
\rightarrow \text { Motivation to travel }\end{array}$ & $\begin{array}{l}\text { Existential } \\
\text { authenticity }\end{array}$ & 0.817 & 0.711 & 0.930 & 0.001 & Accept \\
\hline H5.2 (c) & $\begin{array}{l}\text { Attitude towards local food } \\
\quad \rightarrow \text { Satisfaction }\end{array}$ & $\begin{array}{l}\text { Existential } \\
\text { authenticity }\end{array}$ & 0.386 & 0.302 & 0.478 & 0.001 & Accept \\
\hline
\end{tabular}

\section{DISCUSSION}

\section{The influence of attitudes to local food on tourist behaviour}

The purpose of the first research objective was to establish if tourist attitudes to local food influence destination choice, motivation to travel, satisfaction and perceived authenticity. Overall this study found four key points related to the first research question.

Firstly, attitudes to local food are a determining factor in destination choice $(\beta=0.136 ; p<0.001)$. This significant 'attitudes to local food - destination choice' relationship reasons that local food functions as a destination trigger. As such tourists may choose a particular destination due to the local food it serves and for the anticipated food experiences it provides. As such local food can no longer be viewed as a supporting resource. Rather local food is a destination attraction. Hence, it could be determined that local food and various local food-related experiences are critical factors in enticing tourists to visit a destination (Bjork and Kauppinen-Räisänen, 2017; Su et al., 2018).

Secondly, tourist attitudes to local food do not influence travel motivation $(\beta=-0.89, p<0.100)$. This finding is contrary to previous studies which have suggested that positive attitudes towards local food can influence travel motivation (Bjork and Kauppinen-Räisänen, 2014, 2016, 2017; Hjalager and Richards, 2002; Mak, et al., 2017). Motivation is recognised as a multi-faceted construct consisting of physiological and complex psychological factors and behaviours (Mak, et al., 2012). Travel motivations surface when a tourist wants to satisfy a need or want which cannot be met at home. Therefore, it can be assumed that individuals travel for different reasons, often based on a combination of motives (Su et al., 2018).

Thirdly, it was found that tourist attitudes to local food influence overall holiday satisfaction $(\beta=0.320 ; p<0.001)$. This significant 'attitudes to local food - satisfaction' relationship shows that for tourists with a positive interest in local food, their local food experiences are an important contributor to overall holiday satisfaction. As already 
mentioned, satisfaction is based on an evaluation which meets or exceeds a preconceived expectation (Oliver, 1980). Therefore, it could be argued that local food must meet the expectations of the tourist to guarantee a satisfactory holiday experience. Equally, it can be inferred that bad local food experiences have the potential to induce levels of holiday dissatisfaction. This indicates that local food has the capacity to provide tourists with some of the highest and lowest points of their overall holiday experience. Based on these findings, local food may be a critical factor in tourism, representing a threat and an opportunity for destinations. Research has demonstrated that customer satisfaction significantly influences future tourist behaviour such as revisit intention and positive word-ofmouth (Oliver and Burke, 1999). Therefore, it could be argued that positive local food experiences can influence revisit intention and could encourage positive word of mouth (Sánchez-Cañizares and López-Guzmán, 2012). On the other hand, negative experiences with local food may cause the opposite behaviour.

Fourthly, it was found that tourists with an interest in local food recognise it as an object-related authentic experience $(\beta=0.542 ; p<0.001)$. The finding from this research question implies that tourists with a positive interest in local food, see the tangible significance in local food and understand how it relates to a place and its people. Additionally, tourists with an interest in local food recognise it as an existential authentic experience $(\beta=0.629$; $p<0.001)$. The tourist takes an active role in the experience. The findings suggest that tourists interested in local food see the significance of local food and understand how it can relate to a specific place and its culture. Therefore, by consuming local food, tourists 'are also consuming the meaning behind it' (Sims, 2009, p. 333). In this sense, if eating food on holiday is turned into a tourist activity, rather than merely being regarded as an object, the food constitutes a form of existential authenticity. Understanding, what tourists perceive or evaluate as authentic can enhance the tourist experience and as such, must be considered when developing destination marketing strategies. As such the authenticity of the local food must be interpreted not only through the food product but also in an appealing way, where the tourist can become actively involved in the local food experience.

\section{The influence of authenticity on the relationships between tourist attitudes to local food and travel behaviour}

The second objective aimed to examine if authenticity influences the relationships between tourist attitudes to local food and destination choice, motivation to travel and satisfaction. In this study authenticity was investigated from two perspectives; object-related and existential.

\section{Object-related authenticity}

There were three key findings related to the investigation of object-related authenticity on each of the relationships. Firstly, for those with an interest in local food, object-related authenticity had no influence on destination choice ( $\beta$ $=0.025, p=0.341)$. Hence, the findings imply that the causal relationship between tourist attitudes to local food and destination choice is not influenced by object-related authenticity. This suggests that tourists with an interest in local food are not influenced to choose a destination because of the object-related authentic experiences available. As such tourists are not choosing destinations based on the traditional or unique local food products offered.

Secondly, object-related authenticity had a marginal effect on the relationship between attitudes to local food and motivation to travel $(\beta=0.168, p<0.001)$. Previously, Hypothesis 2 found that tourist attitudes to local food had no direct influence on travel motivation. However, the finding from this hypothesis shows that the relationship between the two is significant when mediated by object-related authenticity. Hence, the causal relationship between tourist attitudes to local food and motivation to travel becomes significant when mediated by object-related authenticity. This shows that for tourists with a propensity for local food, object-related authenticity can motivate travel. Therefore, this research suggests that if destinations wish to motivate those interested in local food to travel, object-related authenticity must be considered in tourism campaigns and in destination promotion.

Thirdly, object-related authenticity had no effect on the relationship between tourist attitudes to local food and satisfaction $(\beta=0.004, p=0$. 833). This infers that for those tourists interested in local food its object-related authenticity has no bearing on holiday satisfaction.

\section{Existential authenticity}

The influence of existential authenticity on the relationships between attitudes to local food and destination choice, motivation to travel and satisfaction found three key points. Firstly, it was determined that the relationship between attitudes to local food and destination choice was influenced by existential authenticity $(\beta=0.618 ; p<0.001)$. This 
result suggests that tourists with a high interest in local food are influenced to choose a destination because of the availability of existential authentic experiences. As such these tourists are selecting destinations based on the cultural or activity-related aspects that local food offers.

Secondly, existential authenticity had a substantial influence on the relationship between attitudes to local food and motivation to travel $(\beta=0.817 ; p<0.001)$. Statistically, this result was greater than the overall effect of object-related authenticity on this relationship. Therefore, it can be concluded that existential authenticity has more influence on the relationship between attitudes to local food and motivation to travel, than object-related authenticity. Consequently, tourists interested in local food are motivated to travel to learn about and participate in food experiences.

Thirdly, it was found that existential authenticity had a sizable effect on the relationship between attitudes to local food and satisfaction $(\beta=0.386 ; p<0.001)$. Therefore, tourists with an interest in local food are not just enjoying the taste of the food, but rather they find pleasure in consuming the meaning around it. In addition, it can be intuitively assumed that if tourists are satisfied with their holiday experience, they may be willing to return to destinations and recommend them to others.

In summary, existential authenticity has an influence on the relationships between attitudes to local food, destination choice, motivation to travel and satisfaction. Whereas, object-related authenticity had only a marginal effect on the relationship between tourist attitudes to local food and motivation to travel. As such, existential authenticity has a crucial role to play in travel behaviour.

A revised conceptual framework based on the results of the investigation into the two research objectives is presented in Figure 3.

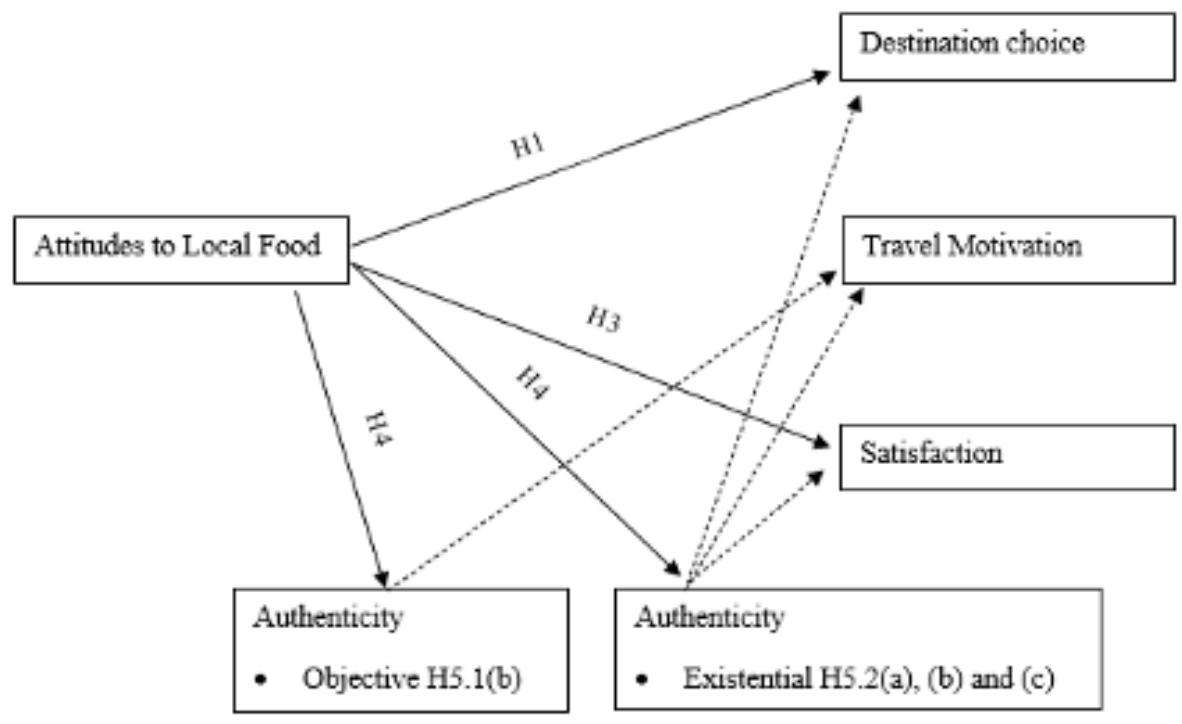

Figure 3: Revised Conceptual Framework: attitudes to local food and travel behaviour mediated by authenticity 


\section{CONCLUSIONS}

The study provides evidence that attitudes to local food are a determinant of destination choice, travel motivation and overall satisfaction. As such this contributes to the field of food tourism by focusing on attitudes to local food as an antecedent which effects destination choice, travel motivation, satisfaction and perceived authenticity. The framework demonstrated that existential authenticity has considerable influence on the relationships between tourist attitudes to local food and destination choice, travel motivation and satisfaction. While object-related authenticity has an impact on the relationship between tourist attitudes to local food and travel motivation.

\section{Theoretical contributions}

The first theoretical contribution of this study is to provide an explanation specific to the influence of tourist attitudes to local food and on travel behaviour. Therefore, this research adds to the existing body of knowledge within food tourism by suggesting that attitudes to local food are an antecedent which influence travel behaviour.

Secondly, this study also contributes by examining the effect of object-related and existential authenticity on the relationships between tourist attitudes to local food and travel behaviour. Additionally, by examining the meditating effects of object-related and an existential authenticity on the relationships between tourist attitudes to local food and destination choice, motivation to travel and satisfaction, the research further confirms recent studies showing the influential role of authenticity in tourism behaviour.

Thirdly, the development of a framework examining the role of tourist attitudes to local food and travel behaviour. The framework also acknowledges the mediating effects of both object-related and existential authenticity. The conceptual framework has been refined based on the results of the investigation, see figure 3 . This framework now offers a more solid foundation for subsequent research.

\section{Managerial Contribution}

From a practical perspective, this paper contributes to a better understanding of the role of local food from a tourist's perspective as a means of destination development. As such the findings show destination marketers, policymakers, local food producers that tourists are inherently interested in local food. As such, the results of this study stress that tourists have an interest in local food and are seeking food experiences linked to locality. This can be achieved by highlighting local food producers, cafes and restaurants in promotional material, social media and websites. Consequently, promoting local food can also generate additional benefits for a region through complementary activities, such as local farming, shops and food production (Sims, 2009).

For destinations marketers, the results also highlight the importance of promoting authentic local food experiences for tourists. The results of this study show that tourists want to actively take part and learn about the culture and heritage of a place through local food. This can be achieved by emphasising the story of the food and its traditions. Local food could be linked with activities available at the destination and used to enhance the experiential aspect of the dining experience. Tourism offerings need to be developed to appeal to the existential authenticity that tourist's desire.

The research findings are currently restricted to the Irish context in which this study was undertaken. That said, food tourism has been studied under a wide array of national settings and, thus, is by no means applicable to merely an Irish context. Therefore, it may be the case that some, if not all, of the research findings, are internationally transferable. To verify this claim, it is recommended that future research of a similar nature should be undertaken in various geographical settings.

Additionally, it is suggested that a qualitative approach could be taken to further investigate the research objectives. Engagement in the research suggested here would ultimately lead to an enhanced understanding of how attitudes to local food can influence travel behaviour.

Moreover, it may help to strengthen the evidence of this study's external reliability, by demonstrating the potential replicability of its results (Bryman, 2008). 
Andersson, T., \& Mossberg, L. (2017). Travel for the sake of food. Scandinavian Journal of Hospitality and Tourism, 17(1), 44-58.

Barclay, D. W., Higgins, C. A., \& Thompson, R. (1995). The partial least squares approach to causal modeling: personal computer adoption and use as illustration. Technology Studies, 2(2), 285-309.

Beer, S. (2008). Authenticity and food experience: Commercial and academic perspectives. Journal of Foodservice, 19, 153-163.

Bell, R., \& Marshall, D., (2003). The construct of food involvement in behavioural research: Scale development and validation. Appetite, 40(3), 235244.

Björk P., \& Kauppinen-Räisänen, H. (2014). Culinarygastronomic tourism - a search for local food experiences. Nutrition and Food Science, 44(4), 294-309.

Björk P., \& Kauppinen-Räisänen, H. (2016). Local food - a source for destination attraction. International Journal of Contemporary Hospitality, 26(2), 177194.

Björk P., \& Kauppinen-Räisänen, H. (2017). Interested in eating and drinking? How food affects travel satisfaction and the overall holiday experience. Scandinavian Journal of Tourism and Hospitality, 17(1), 9-26.

Boesen, M., Sundbo, D., \& Sundbo, J. (2017). Local food and tourism: an entrepreneurial network approach. Scandinavian Journal of Hospitality and Tourism, 17(1), 76-91.

Boniface, P. (2003). Tasting tourism: travelling for food and drink. Aldershot: Ashgate.

Bryman, A. (2008). Social Research Methods. 3rd ed., New York NY: Oxford University Press.

Cetin, G., \& Bilgihan, A. (2016). Components of cultural tourists' experiences in destinations. Current Issues in Tourism, 19(2), 137-154.

Chandralal, L., \& Valenzuela, F. R. (2013). Exploring Memorable Tourism Experiences: Antecedents and Behavioral Outcomes. Journal of Economics, Business and Management, 1(2), 177-81.

Chen, Q., \& Huang, R., (2019). Understanding the role of local food in sustaining Chinese destinations. Current Issues in Tourism, 22(5), 544-560.

Cohen, E., \& Avieli, N. (2004). Food in Tourism: Attraction and Impediment. Annals of Tourism Research, 4, 755-778.
Crompton, J. L. (1979). Motivations for Pleasure Vacations. Annals of Tourism Research, 5(4), 408424.

Dann, G. (1977). Anomie, ego-enhancement and tourism. Annals of Tourism Research, 4, 84-194.

Dann, G. (1981). Tourist motivation- an appraisal. Annals of Tourism Research, 8(2), 187-219.

Ellis, A., Park, E., Kim, S., \& Yeoman, I., (2018). What is food tourism? Tourism Management, 68, 250-263.

Everett, S. (2012). Production Places or Consumption Spaces? The Place-making Agency of Food Tourism in Ireland and Scotland. Tourism Geographies, 14(4), 535-554.

Fields, K. (2002). Demand for the gastronomy tourism product: Motivational factors, In A. Hjalager, \& G. Richards (Eds.), Tourism and gastronomy (pp. 3750). London: Routledge.

Gaskin, J. (2010). Specific Indirect Effects plugin [online], Stat Wiki, available: http://statwiki.kolobkreations. com/index.php?title=Main_Page [accessed 12 Feb 2018].

Gaskin, J. (2012). StatWiki [online], Stats Tools Package, available: http://statwiki.kolobkreations.com/index. php?title=Main_Page [accessed 12 Feb 2018].

Hair, J. F., Black, W. C., Balin, B. J., \& Anderson, R. E. (2013). Multivariate data analysis. New York NY: Maxwell Macmillan.

Hall, C. M., \& Sharples, L. (2003). The consumption of tourism experiences or the experience of consumption? An introduction to the tourism of taste. In C.M. Hall, L. Sharples, R. Mitchell, N. Macionis, \& B. Cambourne (Eds.) Food Tourism Around the World - Development, management and markets (pp. 1-25). Oxford: ButterworthHeinemann.

Henderson, J. (2009). Food tourism reviewed. British Food Journal, 111, 317-326.

Hjalager, A.M. (2003). A typology of gastronomy tourism. In A. Hjalager \& G. Richards (Eds.) Tourism and gastronomy (pp. 35-49). London: Routledge.

Hjalager, A. M., Richards, G. (2002). Still undigested: research issues in tourism and gastronomy. In A.M. Hjalager \& G. Richards (Eds.) Tourism and Gastronomy. London: Routledge.

Jang, S., Liu, Y., \& Namkung, Y. (2011). Effects of authentic atmospherics in ethnic restaurants: Investigating Chinese restaurants. International Journal of Contemporary Hospitality Management, 23(5), 662-680. 
Kauppinen-Räisänen, H., Gummerus, J., \& Lehtola, K., (2013). Remembered eating experiences described by the self, place, food, context and time. British Food Journal, 115(5), 666-685.

Kim, Y. G., Suh, B. W., \& Eves, A. (2010). The relationships between food-related personality traits, satisfaction, and loyalty among visitors attending food events and festivals. International Journal of Hospitality Management, 22(2), 216226.

Kim, Y., and Eves, A. (2012). Construction and Validation of a Scale to Measure Tourist

Motivation to Consume Local Food. Tourism Management, 33, 1458-1467.

Kivela, J., \& Crotts, J. (2009). Understanding travellers' experiences of gastronomy through etymology and narration. Journal of Hospitality and Tourism Research, 33(2), 161-192.

Kivela, J., \& Crotts, J. C. (2006). Tourism and gastronomy: Gastronomy's influence on how tourists experience a destination. Journal of Hospitality and Tourism Research, 30(3), 354-377.

Laura Sidali, K., \& Hemmerling, S., (2014). Developing an authenticity model of traditional food specialties: Does the self-concept of consumers matter? British Food Journal, 116(11) 1692-1709.

López-Guzmán, T. \& Sánchez-Cañizares, S. (2012). Culinary tourism in Córdoba Spain, British Food Journal, 114(2), 168-179.

Lowry, P. B., \& Gaskin, J., (2014). Partial least squares (PLS) structural equation modeling (SEM) for building and testing behavioral causal theory: When to choose it and how to use it. IEEE transactions on professional communication, 57(2), 123-146.

Mak, A. H. N., Lumbers, M., Eves, A., \& Chang, R. (2017). The effects of food-related

personality traits on tourist food consumption motivations. Asia Pacific Journal of Tourism Research, 22(1), 1-20.

Mak, A. H., Lumbers, M., Eves, A., \& Chang, R. C. (2012). Factors Influencing Tourist Food Consumption. International Journal of Hospitality Management, 31(3), 928-936.

McKercher, B. F., Okumus, F. \& Okumus, B. (2008). Food tourism as a viable market segment: it's all how you cook the numbers! Journal of Travel and Tourism Marketing. 25(2), 137-148.

Mitchell, R., \& Hall, M. (2003). Consuming tourists: food tourism consumer behaviour. In M. Hall, L. Sharples, R. Mitchell, N. Macionis, \& B. Crambourne, B. (Eds.). Food Tourism around the World. Oxford: Butterworth Heinemann.
Okumus B., Okumus, F., \& McKercher, B. (2007). Incorporating local and international cuisines in the marketing of tourism destinations: The cases of Hong Kong and Turkey. Tourism Management, 28(1), 253-261.

Oliver, R. L. (1980). A Cognitive Model of the Antecedents and Consequences of Satisfaction Decisions. Journal of Marketing Research, 17, 46-49.

Oliver, R. L., \& Burke, R. R. (1999). Expectation Processes in Satisfaction Formation: A Field Study. Journal of Service Research, 1(3), 196-214.

Özdemir, B. \& Seyitoğlu, F. (2017). A conceptual study of gastronomical quests of tourists: Authenticity or safety and comfort?. Tourism Management Perspectives, 23, 1-7.

Pallant, J. (2011). SPSS Survival Manual: A step by step guide to data analysis using SPSS. 4th ed., Australia: Allen \& Unwin.

Patton, M. (2001). Qualitative research and evaluation methods. California CA: Sage.

Ram, Y., Bjork, P. \& Weidenfeld, A. (2016). Authenticity and place attachment of major visitor attractions. Tourism Management, 52, 110-122.

Richards, G. (2012) Food and the tourism experience: major findings and policy orientations. In D. Dodd, (Ed.) Food and the Tourism Experience (pp. 1346). Paris: OECD.

Richards, G. (2012). An overview of food and tourism trends and policies. In Food and the tourism experience: The OECD-Korea Workshop, OECD Studies on Tourism: OECD Publishing.

Robinson, R.N.S., \& Clifford, C. (2012). Authenticity and Foodservice Festival Experiences. Annals of Tourism Research, 39, 2, 571-600.

Robinson, R. N. S., \& Getz, D. (2016). Food Enthusiasts and Tourism, Exploring Food

Involvement Dimensions. Journal of Hospitality and Tourism Research. 40(4), 432-455.

Sánchez-Cañizares, S. M., \& López-Guzmán, T. (2012). Gastronomy as a tourism resource: profile of the culinary tourist. Current Issues in Tourism, 15(3), 229-245.

Sims, R. (2009). Food, place and authenticity: local food and the sustainable tourism experience. Journal of Sustainable Tourism, 17(3), 321-336.

Smith, S., \& Costello, C., (2009). Segmenting visitors to a culinary event: Motivations, travel behavior, and expenditures. Journal of Hospitality Marketing \& Management, 18(1), 44-67.

Su, C.S., 2013. An importance-performance analysis of dining attributes: A comparison of individual and packaged tourists in Taiwan. Asia Pacific Journal 
of Tourism Research, 18(6), 573-597.

Su, D. N., Johnson, L.W. \& O'Mahony, B., (2018). Analysis of push and pull factors in food travel motivation. Current Issues in Tourism, Nov. 30, 1-15.

Tabachnick, B. G., \& Fidell, L. S. (2013). Using Multivariate Statistics. Boston MA: Pearson.

Taylor, J. P. (2001). Authenticity and sincerity in tourism. Annals of Tourism Research, 28(1), 7-26.

United Nations World Tourism Organisation (UNTWO).
(2012). Global report on food tourism. [online], available: https://webunwto.s3-eu-west-1. amazonaws.com/imported_images/37599/global_ report_on_food_tourism.pdf [accessed 23 January 2019].

Williamson, J. \& Hassanli, N., (2020). It's all in the recipe: How to increase domestic leisure tourists' experiential loyalty to local food. Tourism management perspectives, 36, 100745. 